\title{
Assessing the Relationship between Efficiency, Capital and Risk of Commercial Banks in Bangladesh
}

\author{
Nazmoon Akhter ${ }^{1}$ \\ ${ }^{1}$ Lecturer, Faculty of Business Administration, BGC Trust University Bangladesh, Bangladesh \\ Correspondence: Nazmoon Akhter, Lecturer, Faculty of Business Administration, BGC Trust University \\ Bangladesh, Chandanaish, Chittagong, Bangladesh. E-mail: akhternazmoon@gmail.com
}

Received: October 11, 2018

Accepted: November 20, 2018

Online Published: December 18, 2018

doi:10.5539/ijbm.v14n1p55

URL: https://doi.org/10.5539/ijbm.v14n1p55

\begin{abstract}
Increased competition and problem loan in the banking sectors force banks to operate its activities more efficiently. However, bank's efficiency, capital and risk are interrelated. The present study is made on assessing the inter-temporal relationship between efficiency, capital and risk of commercial banks in Bangladesh during the period 2011-2016 by setting simultaneous equation. The study uses three-stage least square model (3SLS) and dynamic panel generalized method of moments (GMM) model to estimate efficiency-capital-risk relationship. The study reports that both models provide consistent result regarding the relationship of bank's operational efficiency with capital and risk and inconsistent result about the relationship between capital and risk. The study concludes that a U-shaped relationship is exited in the 3SLS model of efficiency-capital-risk relationship as banks' operational efficiency and risk have positive relationship with capital and bank size, indicating that with increased capital and bank size, bank's operational efficiency is improved at decreasing rate due to increase in bank's risk.
\end{abstract}

Keywords: bank's operational efficiency, capital, dynamic panel GMM, risk, 3SLS

\section{Introduction}

As monetary institution, banking system dominates a country's economic growth largely due to enjoy monopoly position in the financial market. Generally, the main activities of banks is considered as repository of money, as it takes money in term of deposit from public and then uses for various advances and investment sectors to earn profit. On the other hand, a country's economic growth and efficiency is being hindered because of the bank's increasing problem loans as the resources are locked up in unprofitable sectors. For this reason, the operations of the banking system are needed to be efficient to ensure economic sustainability. Besides, all the banks are required to operate closer to the best practice due to increase competition in the banking sector. However, increased competition influences greater risk-taking behavior and reduces the market power and charter value of the bank. (Salas \& Saurina, 2003; Hellmann et al., 2000). In this regard, regulatory body of the banks needs to focus on capital requirement and proper supervision to identify the possible incentives of taking higher risks (Mosko \& Bozdo, 2015).

Although banking system is supposed to play a crucial role in the efficient allocation of resources in an economy, its' continuing failures due to high non-performing loans are affecting its' sustenance, the country's efficiency and productivity and constraining the scope of businesses and industries that have a good potentiality to grow and increase the strength of the economy in the long run. Thus, the credit crisis highlights the necessity of analyzing bank risks in an environment of improved bank efficiency and lower bank capital.

In the context of Bangladesh, the banking system comprised of six State-owned Commercial Banks (SCBs), fourty Private Commercial Banks (PCBs) and nine Foreign Commercial Banks (FCBs) during 2017. Bangladesh Bank (BB), central bank of Bangladesh, reports that the total non-performing loans of banking sector is Tk 80397 crore as of September 2017 which is about 10.67\% of all outstanding loans. During 2017, the SCBs are the worst performers as their problem loan stands at Tk 44126 crore or $55 \%$ of total. Besides, these banks have shortage of capital which is Tk 12683 crore at the end of june 2017. Such situations have wrecked profitability and capital adequacy of banks. The reasons behind these are enormous corruption and inefficiency. Thus taking these entire figures into consideration, it has become necessary to assess the relationship between bank efficiency, capital and risk in Bangladesh banking system. 
Surprisingly, a number of studies have taken place on identifying influencing factors of efficiency, capital and risk separately in banking sectors in Bangladesh. But, there is no such a study available on modeling a relationship between bank efficiency, capital and risk in banking industry of Bangladesh. Thus, the present is carried out on assessing the relationship between bank efficiency, capital and risk in Bangladesh banking system.

\section{Literature Review}

Bank's operational efficiency, capital and risk are interrelated and various empirical results report that the relationship between bank's operational efficiency, capital and risk is different across countries. Tan and Floros (2013) use three-stage least square method to assess the relationship between bank efficiency, capital and risk of Chinese commercial banking industry. In their study, they consider four measures to indicate risk which are loan loss provision to total loans (LLPTL) ratio, volatility of return on assets (ROA), volatility of return on equity (ROE) and Z-score. They find that a significant and negative relation exists between risk (Z-score) and capitalization while a significant and positive relation exists between risk (LLPTL) and efficiency of Chinese banks. They also explain that as bank specific variables, bigger banks (in terms of total assets) have positive relation and higher liquidity has negative relation with bank efficiency. Moreover, they suggest that banks having higher liquidity level are more capitalized. They conclude that banks are motivated to do their lending activities with higher risk in order to increase competition in the banking sector. In this regards, Kwan and Eisenbeis (1997) use a simultaneous equation framework to analyze the interrelationships between bank interest rate and credit risk-taking, capitalization and operating efficiency. They find that efficiency and capital are relevant drivers of bank risk and explain that highly capitalized banks operate their activities more efficiently than less capitalized banks and inefficient banks are more vulnerable to risk-taking than high performance banking organizations. Supporting this view, Fiordelisi et al (2010) seek to establish the inter-temporal relationship among efficiency, capital and risk for commercial banks operating in the European Union. They conclude that lower efficiency indicates greater future risks whereas efficiency improvement leads to shore up bank's capital positions. They suggest that long term efficiency ensures financial stability of banks in the future market. Further, Fiordelisi et al (2011) stated that banks that operate inefficiently, have higher risk levels and banks with higher level of capital increase their efficiency. In this regards, Altunbas et al (2007) seek to examine the relationship between capital, risk and efficiency in European banking industry and find that less efficient banks tend to have higher capital levels and lower levels of credit risk. They also find positive relationship between risk on the level of capital (and liquidity), indicate that regulators' preference for capital can be used as a mean of restricting risk-taking activities. Das and Ghosh (2004) report that bank's risk and capital levels are simultaneously related and explain that banks reduce the effects of increase in capital by decreasing asset risk posture and vice-versa. Further, Das and Gosh (2006) find a positive relationship between bank capital and operating efficiency and explain that banks with sufficient capital are considered financially healthier and safer against credit risk which will lead to improved efficiency. However, Jensen and Meckling (1976), Fama (1980) and Fama and Jensen (1983) explain that firms with lower capital weakens owner control over management which in turn make management freer to follow its own agenda and thus provide with fewer incentives to be efficient. Moreover, Hughes and Mester (2013) explain that bank's production decisions (including their mix of assets, asset quality, off-balance sheet hedging activities, capital structure, debt maturity and resources allocated to risk management) are affected by the choice of risk which ultimately affects bank's cost and profitability.

Various research papers expose the relationship between bank efficiency, capital and risk by considering moral hazard, bad management and agency cost hypotheses. According to Calomiris and Kahn (1991), a negative relation exists between capital regulation and performance due to agency cost between managers and shareholders. They explain that conflicts between managers and shareholders are increased when capital ratios are higher due to the discipline imposed on manager behavior by debt repayment requirements. In this case, Demsetz et al (1996), Salas and Saurina (2003), Gorton and Rosen (1995) and Jacques and Nigro (1997) show a negative relationship between capital and risk, indicating that bank managers tend to take on more risk especially when banks have lower capital level that indicates moral hazard hypothesis. With regards to, Hughes and Moon (1995) report that the role of efficiency is crucial for evaluating the relationship between risk and capital, explaining that efficient banks are more flexible in terms of their capital level and risk profile than less efficient banks. They explain that less efficient banks with lower level of capital tend to take more risk to compensate for lost return because of considering moral hazard. On the contrary, Ediz et al (1997), Rime (2001) and Iannotta et al (2007) stated that bank's capital and risks are positively correlated, explaining that bank capital can be used to compensate for their asset risk. In this case, Lotto, J. (2018) outlines the impact of capital regulations on operating efficiency. He finds a positive and significant relationship between capital ratio and bank's operating efficiency which means that capital adequacy provides safety cushion for banks financial stability and prevents 
moral hazard problems between shareholders and debt-holders to increase bank's operating efficiency. He also finds a negative relationship between non-performing loans and bank's operating efficiency which explains that a significant amount of bank's loan and advances will attract a greater chance of being default and such types of loans are of little importance in determining bank's operational efficiency. He concludes that bank management needs to be more careful in the loan screening process to decline the incidence of non-performing loans. Berger and De Young (1997) explain that banks with lower levels of capital and operating efficiency have higher cost, result in increasing problem loans. In this regards, Williams (2004) used granger-causality techniques to analyze the inter-temporal relationships among problem loans, cost efficiency and financial capital and reported that lower efficiency banks make poor quality loans due to bad management. Based on these studies, we use simultaneous equation to assess the relationship between efficiency, capital and risk of commercial banks in Bangladesh.

\section{Research Design}

\subsection{Data collection}

As the main objective of the study is to assess the relationship between efficiency, capital and risk of commercial banks, annual reports of 30 scheduled commercial banks in Bangladesh (Appendix: Table 1) have been collected for the period from 2011 to 2016. During 2011 the number of scheduled commercial banks in Bangladesh was 34. The study tries to cover most of the scheduled commercial banks in Bangladesh that have available data for at least 6 years.

\subsection{Variables}

\subsubsection{Dependent Variables}

The study uses three variables to define dependent variables in order to examine inter-temporal relationship between efficiency, capital and risks of the sampled commercial banks in Bangladesh.

\subsubsection{Operational Efficiency}

Some authors measure Operational Efficiency Ratio (OER) by dividing operational expenses by interest and non-interest income where a decrease in the OER is desirable, explains that bank is able to generate more earnings than its spendings (Allen and Rai 1996; Yeh 1996; Halkos and Salamouris 2004). On the other hand, several researchers followed the reciprocal of the ratio (Amer 2011, Odunga 2016). Such ratio is computed by dividing interest and non-interest income by operational expenses which is followed in this study. The calculation of OER in the study is as follows:

$$
\mathrm{OER}=\frac{\text { Interest Income }+ \text { Non }- \text { interest Income }+ \text { Securities Gains (Losses) }}{\text { Interest Expenses }+ \text { Non }- \text { interest Expenses + Provision for Loan Loss }+ \text { Taxes }}
$$

Therefore, a higher OER is desirable as it reflects the pricing and production efficiency of the bank.

\subsubsection{Bank Risk Taking}

In the study, credit risk is considered and Loan Loss Provision to Total Loans ratio (LLPTL) is used to define the risk of bank (Tan and Floros, 2013).

\subsubsection{Bank Capital}

The study used book value of Equity to Total Assets ratio (ECTA) to show the bank capital (Tan and Floros, 2013).

\subsubsection{Independent Variables}

The following table shows selected independent variables where such variables are considered on the basis of literature reviews.

Table 2. Selected Independent Variables

\begin{tabular}{|c|c|c|c|}
\hline \multicolumn{2}{|c|}{ Independent Variables (Bank Specific Variables) } & \multirow{2}{*}{$\begin{array}{l}\text { Description } \\
\text { Log of Total Assets }\end{array}$} & \multirow{2}{*}{$\begin{array}{l}\text { Source } \\
\text { Kwakwala, B. K. (2015). }\end{array}$} \\
\hline Bank Size & LogTA & & \\
\hline Profitability & ROA & Return on Assets & Rime, B. (2001) \\
\hline Liquidity & LTA & Loan Ratio (Net Loan to Total Assets) & Williams, J.(2004) \\
\hline \multirow{3}{*}{ Asset Quality } & LDR & Net Loan to Total Deposits & Kwakwala, B. K. (2015). \\
\hline & \multirow[t]{2}{*}{ NCOAGL } & & Kwan, S. and Eisenbeis, R.(1997) \\
\hline & & Net Charge-off to Average Gross Loan (Bad Loan) & \\
\hline
\end{tabular}

Note. Author's Survey 


\subsection{Empirical Methodology}

The study follows two estimation models i.e. three-stage least square (3SLS) estimation and dynamic panel GMM (i.e., generalized method of moments) model where 3SLS estimation is used to address endogeneity, cross-correlation between the error terms (Zellner and theil, 1962) and dynamic panel GMM model (Arellano and Bover, 1995; Blundell and Bond, 2000) is used to address potential endogeneity, heteroscedasticity and autocorrelation problems.

The following simultaneous equation consisting of three linear equations shows the empirical model to be estimated in the study:

$$
\begin{aligned}
& \text { OER } i t=f(\mathrm{OER} i, t-1, \text { ECTA } i, t, \text { LLPTL } i, t, \operatorname{LogTA} i, t, \text { NCOAGL } i, t, \text { LDR } i, t, \text { TIME EFFECT DUMMIES } i, t) \\
& \text { ECTA } i t=g(\text { ECTA } i, t-1, \text { LLPTL } i, t, \text { OER } i, t, \text { LogTA } i, t, \text { NCOAGL } i, t, \text { ROA } i, t, \text { TIME EFFECT DUMMIES } i, t) \\
& \text { LLPTL } i t=h(\text { LLPTL } i, t-1, \text { ECTA } i, t, \text { OER } i, t, \text { LogTA } i, t, \text { NCOAGL } i, t, \text { LTA } i, t, \text { TIME EFFECT DUMMIES } i, t)
\end{aligned}
$$

Here:

OER $i, t=$ Operational Efficiency ratio

ECTA $i, t=$ Equity to Total Assets ratio

LLPTL $i, t=$ Loan Loss Provision to Total Loans ratio

$\operatorname{LogTA} i, t=\log$ of Total Assets

NCOAGL $i, t=$ Net Charge-off to Average Gross Loan ratio (Bad Loan)

LDR $i, t=$ Net Loan to Total Deposits ratio

ROA $i, t=$ Return on Assets ratio

LTA $i, t=$ Net Loan to Total Assets ratio

TIME EFFECT DUMMIES $i, t=1$ for year $\mathrm{t}$ and zero for otherwise.

\section{Discussion of Findings}

\subsection{Descriptive Analysis}

Table 3 shows descriptive analysis of selected variables of the sampled commercial banks in Bangladesh.

Table 3. Descriptive Analysis

\begin{tabular}{llllll}
\hline \multicolumn{2}{c}{ Descriptive Analysis } & & & & \\
Variable & Observations & Mean & Std. Dev. & Min & Max \\
\hline ECTA & 180 & 0.08493 & 0.019597 & 0.018932 & 0.154282 \\
LLPTL & 180 & 0.011026 & 0.012188 & -0.00114 & 0.11703 \\
OER & 180 & 1.124058 & 0.086385 & 0.71432 & 1.767872 \\
LogTA & 180 & 25.95143 & 0.516428 & 24.93716 & 27.42935 \\
ROA & 180 & 0.011106 & 0.009217 & -0.0492 & 0.07 \\
NCOAGL & 180 & 0.046889 & 0.036614 & 0.000171 & 0.231823 \\
LTA & 180 & 0.64719 & 0.086605 & 0.064276 & 0.796127 \\
LDR & 180 & 0.884261 & 0.341989 & 0.538146 & 3.411136 \\
\hline
\end{tabular}

Note. Author's Computation.

Table 3 reports that ECTA takes average value $8.49 \%$ which means that banks with lower ECTA ratio spent large proportion of its earnings in paying interest. The average value of LLPTL is $1.1026 \%$ which reports that the selected commercial banks keep a significant portion of income as provision to handle credit risk. Besides, the average value of OER is $112.40 \%$ which indicates that on average banks are able to generate revenues in order to cover its total operating costs. The average value of $\operatorname{LogTA}$ is $25.95 \%$ ranging from $24.93 \%$ to $27.43 \%$. Here, ROA's average value is $1.11 \%$, means that banks' management efficiency is low during the study period. Moreover, the average of NCOAGL is $4.69 \%$ indicates that the selected banks have a significant amount of loan as bad loan. The average of LTA record is $64.72 \%$, indicates an aggressive lending policy where lower ratios ( 0.40 to lower) are considered better debt ratio from a pure risk perspective. However, the average value of LDR is $88.42 \%$ with maximum value $341 \%$, reflects that some banks need to be efficient in conducting credit policies. 


\subsection{Correlations Analysis}

Pairwise Pearson's correlation matrix is performed to judge the potential multicollinearity concerns as follows:

Table 4. Correlation Analysis

\begin{tabular}{lllllllll}
\hline \multicolumn{2}{l}{ Correlation } & Analysis & & & & & & \\
& ECTA & LLPTL & EEF & LogTA & ROA & NCOAGL & LTA & LDR \\
\hline ECTA & 1 & & & & & & & \\
LLPTL & $-0.2078^{* * *}$ & 1 & & & & & & \\
OER & $0.4157^{* * *}$ & $-0.4993^{* * *}$ & 1 & & & & & \\
LogTA & $-0.2394^{* * *}$ & $0.2266^{* * *}$ & -0.0931 & 1 & & & & \\
ROA & $0.4495^{* * *}$ & $-0.581^{* * *}$ & 0.5784 & $-0.274^{* * *}$ & 1 & & & \\
NCOAGL & $-0.3609^{* * *}$ & $0.4418^{* * *}$ & -0.253 & $0.4236^{* * *}$ & $-0.4576^{* * *}$ & 1 & & \\
LTA & $0.2291^{* * *}$ & $-0.1259^{*}$ & 0.0688 & -0.2965 & $0.2448^{* * *}$ & $-0.5303^{* * *}$ & 1 & \\
LDR & -0.0825 & -0.046 & 0.2159 & $-0.0188^{* * *}$ & -0.0541 & $0.3704^{* * *}$ & -0.068 & 1 \\
\hline
\end{tabular}

Note. Significance: $*=\mathrm{p}<0.10, * *=\mathrm{p}<0.05, * * *=\mathrm{p}<0.01$.

The results in table 4 show that there is no multicollinearity between the selected variables, as their coefficient values are less than 0.70 (Kenedy, 2008).

\subsection{Empirical Results}

In this section, the study reports the results of empirical analysis. For this, the study performs three-stage least square (3SLS) model and dynamic panel GMM model to get robust results about bank's efficiency-capital-risk relationship which is shown in the following table:

Table 5. Empirical results

\begin{tabular}{|c|c|c|c|c|c|c|}
\hline \multirow[t]{2}{*}{ Variables } & \multicolumn{3}{|c|}{3 Stage Least Square Method (3SLS) } & \multicolumn{3}{|c|}{ Dynamic Panel GMM } \\
\hline & EEF & ECTA & LLPTL & EEF & ECTA & LLPTL \\
\hline \multirow[t]{2}{*}{ OER $t-1$} & -0.02082 & & & -0.01013 & & \\
\hline & $(0.021194)$ & & & $(0.139518)$ & & \\
\hline \multirow[t]{2}{*}{ ECTA $t-1$} & & $0.544152 * * *$ & & & $0.760093 * * *$ & \\
\hline & & $(0.057672)$ & & & $(0.061832)$ & \\
\hline \multirow[t]{2}{*}{ LLPTL $t-1$} & & & 0.059563 & & & $0.297926^{* * *}$ \\
\hline & & & $(0.048837)$ & & & $(0.085983)$ \\
\hline \multirow[t]{2}{*}{ ECTA } & $1.597673^{* * *}$ & & $0.233217 * * *$ & $1.435422^{* * *}$ & & 0.072025 \\
\hline & $(0.361341)$ & & $(0.054934)$ & $(0.356502)$ & & $(0.093546)$ \\
\hline \multirow[t]{2}{*}{ LLPTL } & $-6.30774 * * *$ & $0.687914 * *$ & & $-3.07652^{* * *}$ & -0.04732 & \\
\hline & $(0.803734)$ & $(0.296542)$ & & $(0.65093)$ & $(0.067546)$ & \\
\hline \multirow[t]{2}{*}{ OER } & & $0.133436 * * *$ & $-0.15437 * * *$ & & $0.081124 * * *$ & $-0.13062 * * *$ \\
\hline & & $(0.027578)$ & $(0.016989)$ & & $(0.018734)$ & $(0.029419)$ \\
\hline \multirow[t]{2}{*}{$\operatorname{LogTA}$} & $0.028511 * *$ & -0.00251 & $0.004263 * *$ & 0.013673 & -0.00105 & 0.002366 \\
\hline & $(0.011999)$ & $(0.00215)$ & $(0.001727)$ & $(0.012045)$ & $(0.001724)$ & $(0.00255)$ \\
\hline \multirow[t]{2}{*}{ NCOAGL } & 0.646614 & $-0.09201^{* *}$ & $0.099951^{* * *}$ & 0.151005 & -0.01619 & 0.083254 \\
\hline & $(0.202113)$ & $(0.039273)$ & $(0.025868)$ & $(0.217245)$ & $(0.033356)$ & $(0.055933)$ \\
\hline \multirow[t]{2}{*}{ LDR } & 0.001644 & & & $-0.02283 * *$ & & \\
\hline & $(0.008668)$ & & & $(0.009822)$ & & \\
\hline \multirow[t]{2}{*}{ ROA } & & $0.402476^{* *}$ & & & 0.061327 & \\
\hline & & $(0.19397)$ & & & $(0.080155)$ & \\
\hline \multirow[t]{2}{*}{ LTA } & & & 0.001926 & & & $0.024666^{*}$ \\
\hline & & & $(0.004999)$ & & & $(0.012968)$ \\
\hline \multirow[t]{2}{*}{ Year1 } & $0.057006^{* * *}$ & $0.009124 * *$ & $0.008806^{* * *}$ & \multirow{2}{*}{\multicolumn{2}{|c|}{ (Omitted for collinearity ) }} & \\
\hline & $(0.020095)$ & $(0.004076)$ & $(0.003045)$ & & & \\
\hline \multirow[t]{2}{*}{ Year2 } & 0.008094 & 0.000226 & 0.001505 & -0.02137 & $-9.1 \mathrm{E}-05$ & 0.004496 \\
\hline & $(0.01932)$ & $(0.003258)$ & $(0.002755)$ & $(0.024874)$ & $(0.001911)$ & $(0.003157)$ \\
\hline
\end{tabular}




\begin{tabular}{|c|c|c|c|c|c|c|}
\hline Year3 & $\begin{array}{l}-0.01434 \\
(0.018499)\end{array}$ & $\begin{array}{l}0.009731 * * * \\
(0.003143)\end{array}$ & $\begin{array}{l}-0.00249 \\
(0.002714)\end{array}$ & $\begin{array}{l}-0.01324 \\
(0.020012)\end{array}$ & $\begin{array}{l}0.009062 * * * \\
(0.001883)\end{array}$ & $\begin{array}{l}-0.00312 \\
(0.002557)\end{array}$ \\
\hline Year4 & $\begin{array}{l}-0.00586 \\
(0.018187)\end{array}$ & $\begin{array}{l}0.006889 * * \\
(0.003035)\end{array}$ & $\begin{array}{l}-0.00071 \\
(0.002637)\end{array}$ & $\begin{array}{l}-0.00858 \\
(0.015123)\end{array}$ & $\begin{array}{l}0.00664 * * * \\
(0.00176)\end{array}$ & $\begin{array}{l}0.001031 \\
(0.002997)\end{array}$ \\
\hline Year5 & $\begin{array}{l}-0.0119 \\
(0.018101)\end{array}$ & $\begin{array}{l}0.008514 * * * \\
(0.003025)\end{array}$ & $\begin{array}{l}-0.00177 \\
(0.002617)\end{array}$ & $\begin{array}{l}-0.01139 \\
(0.010693)\end{array}$ & $\begin{array}{l}0.007803 * * * \\
(0.002481)\end{array}$ & $\begin{array}{l}-0.00059 \\
(0.002239)\end{array}$ \\
\hline _cons & $\begin{array}{l}0.304027 \\
(0.318185)\end{array}$ & $\begin{array}{l}-0.05942 \\
(0.053606)\end{array}$ & $\begin{array}{l}0.046635 \\
(0.047799)\end{array}$ & $\begin{array}{l}0.705984 * * \\
(0.307184)\end{array}$ & $\begin{array}{l}-0.04938 \\
(0.047696)\end{array}$ & $\begin{array}{l}0.065641 \\
(0.073509)\end{array}$ \\
\hline $\mathrm{R}-\mathrm{sq}$ & 0.2852 & 0.5589 & 0.1563 & & & \\
\hline F-Stat & $13.98 * * *$ & $30.84 * * *$ & $24.21 * * *$ & $48.81 * * *$ & $110.08 * * *$ & $5.64 * * *$ \\
\hline Sargan Test & & & & 0 & 0 & 0 \\
\hline Hansen Test & & & & 0.999 & 1 & 1 \\
\hline $\mathrm{AR}(1)$ & & & & 0.33 & 0.002 & 0.227 \\
\hline $\operatorname{AR}(2)$ & & & & 0.967 & 0.954 & 0.537 \\
\hline Observations & 180 & 180 & 180 & 180 & 180 & 180 \\
\hline
\end{tabular}

Note. Significance: $*=\mathrm{p}<0.10, * *=\mathrm{p}<0.05, * * *=\mathrm{p}<0.01$.

As shown in Table 5, 3SLS estimation shows that operational efficiency, capital and risk of selected commercial banks are significantly interrelated. However, bank's capital and risk are not significantly interrelated and only bank's operational efficiency is significantly interrelated with capital and risk under dynamic panel GMM model.

As dependent variable, bank's operational efficiency (OER) has positive relationship with ECTA and negative relationship with LLPTL under both 3SLS and dynamic panel GMM models, has positive relationship with LogTA under 3SLS model and negative relationship with LDR under dynamic panel GMM model. The results explain that with the increase in bank size, bank's operational efficiency is increased. Besides, bank's operational efficiency is improved by keeping larger capital and lowering moral hazard (Mosko and Bozdo, 2015). Further, the negative relationship between OER and LDR indicates that bank's operational efficiency is increased by decreasing loan to deposit ratio as high LDR causes liquidity risk for banks (Soedarto, M. 2004).

As bank's capital ratio, ECTA has positive relation with Lag ECTA and OER under both 3SLS and dynamic panel GMM models, has positive relation with LLPTL and ROA and negative relation with NCOAGL under 3SLS. Such situations explain that decrease in bad loan, increase in earnings, bank's operational efficiency and bank risk influence bank's capital to provide safety cushion in the future. Supporting this findings, Deelchand and Padgett (2009) report that with the increase in portfolio risk, bank's capital is increased to keep up their capital buffer and Hughes and Mester (1998) explain that bank's capital and risk are likely to be influenced by its efficiency. Besides, the positive relation between ECTA and ROA explains that profitable banks are more capable to improve their capitalization through retained earnings or equity issues (Rime, 2001).

As bank risk-taking ratio, LLPTL has negative relationship with bank's operational efficiency (OER) under both 3SLS and dynamic panel GMM models, has positive relationship with ECTA, LogTA, NCOAGL under 3SLS model and has positive relation with Lag LLPTL and LTA under dynamic panel GMM model. The result explains that inefficient banks are more vulnerable to risk-taking than efficient one (Kwan and Eisenbeis, 1997). Besides, Ediz et al (1997) reported that the positive relation between risk and capital is influenced by bank's capital regulation effectively. Moreover, with the increase in bank's size and capital, inefficient banks intend to provide more loans to avoid idle money that will increase bank's risk because of having propensity to incur bad loan. Thus, banks should formulate a policy of scrutinizing a borrower's business extensively to avoid reckless lending that would increase the level of unsecured credits in bank's portfolio that will increase non-performing loans which in turn may lead to high level of loan loss provisions by banks (Odunga, 2016).

Interestingly, the overall empirical results under 3SLS model disclose that a U-shaped relationship is found in the model of efficiency-capital-risk relationship. The results explain that with the increase in capital and bank size, bank's operational efficiency is improved at a decreasing rate. Because, with increased bank size and capital, banks have more available funds to invest that will increase loan growth rate. These increased loan growth rate will increase the level of unsecured credits in bank's portfolio that eventually may lead to increase non-performing loans which may influence high level of loan loss provisions by banks.

\section{Conclusion}

The economy of Bangladesh has tremendous potentiality where efficient intermediation of banks is vital to 
ensure its growth and subsequent development. On the contrary, the country's economy is also threatened by the bank's increasing credit risk, resulting from increasing non-performing loans day by day. Besides, increased competition in the banking sector reduces bank's market power and charter value that may lead banks to greater risk-taking. To find out the reason for this, the study investigates the inter-temporal relationship between efficiency, capital and risk of commercial banks in Bangladesh by setting simultaneous equation. The study uses three-stage least square (3SLS) model and dynamic panel GMM model where both models disclose that bank's operational efficiency has significant relationship with capital and risk. The positive relationship of bank's operational efficiency with capital indicates that efficient banks are better capitalized and higher capital levels have a positive impact on efficiency levels. Whereas, the negative relationship between bank's operational efficiency and risk support moral hazard and bad management hypotheses which explain that inefficient banks undertake more risk and decline in efficiency lead to increased risk-taking respectively. The study finds inconsistent results about the relationship between bank risk-taking and capital where 3SLS model shows a positively significant relationship and GMM shows no significant relationship between them.

Thus, the overall empirical results under 3SLS model highlight that a U-shaped relationship is exited in the model of efficiency-capital-risk relationship as banks' operational efficiency and risk have positive relationship with capital and bank size, reporting that with capital and bank size, bank's operational efficiency is improved at decreasing rate due to increase in bank's risk.

The study captures internal factors of commercial banks to assess the efficiency-capital-risk relationship. To develop an integrated model it needs to consider many other factors such as GDP, Inflation rate, skill and qualification of employee, value of collateral, role of technology, ownership structure etc.

\section{References}

Allen, L., \& Rai A. (1996). Operational Efficiency in Banking: An International Comparison. Journal of Banking \& Finance, 20(4), 655-672.

Altunbas, Y., Carbo, S., Gardener, E. P. M., \& Molyneux, P. (2007). Examining the Relationships between Capital, Risk and Efficiency in European Banking. European Financial Management, 13, 49-70.

Amer, H. M., Moustafa, W., \& Eldomiaty, T. (2011). Determinants of Operating Efficiency for Lowly and Highly Competitive Banks in Egypt. Cambridge Business \& Economics Conference.

Arellano, M., \& Bover, O. (1995). Another Look at the Instrumental Variable Estimation of Error Components Models. Journal of Econometrics, 68, 29-51.

Berger, A.N., \& De Young, R. (1997). Problem Loans and Cost Efficiency in Commercial Banking. Journal of Banking and Finance, 21, 849-70.

Blundell, R., Bond, S., \& Windmeijer, F. (2000). Estimation in Dynamic Panel Data Models: Improving on the Performance of the Standard GMM Estimator. Advances in Econometrics, 15, 53-91.

Calomiris, C. W., and Kahn, C. M. (1991). The Role of Demandable Debt in Structuring Optimal Banking Arrangements. American Economic Review, 81(3), 497-513.

Das, A., \& Ghosh, S. (2004). Risk, Capital and Operating Efficiency: Evidence from Indian Public Sector Banks. Indian Journal of Economics and Business, 3, 147-164.

Das, A., \& Saibal, G. (2006). Financial Deregulation and Efficiency: An Empirical Analysis of Indian Banks During the Post Reform Period. Review of Financial Economics, 15, 193-221.

Deelchanda, T., \& Padgett, C. (2009). The Relationship between Risk, Capital and Efficiency: Evidence from Japanese Cooperative Banks. In ICMA Centre Discussion Papers in Finance. DP2009-12. University of Reading.

Demsetz, R.S., Saindenberg, M.R., \& Strahan, P.E. (1996). Banks with Something to Lose: The Disciplinary Role of Franchise Value. Federal Reserve Bank of New York Economic Policy Review, 2, 1-14.

Editz, T., Michael, I., \& Perraudin, W. (1998). The Impact of Capital Requirements on U.K. Bank Behaviour. Reserve Bank of New York Policy Review, 4, 15-22.

Fama, E. (1980). Agency Problems and the Theory of the Firm. Journal of Political Economy, 88(2), 288-307.

Fama, E., \& Jensen, M. C. (1983). Separation of Ownership and Control. Journal of Law and Economics, 26(2), 301-25. 
Fiordelisi, F., \& Molyneux, P. (2010). The Determinants of Shareholder Value in European Banking. Journal of Banking and Finance, 34, 1189-1200.

Fiordelisi, F., Marques-lbanez, D., \& Molyneux, P. (2011). Efficiency and Risk in European Banking. Journal of Banking and Finance, 35, 1315-1326.

Gorton, G., \& Rosen, R. (1995). Corporate Control, Portfolio Choice and the Decline of Banking. Journal of Finance, 50(5), 1377-1420.

Halkos, G. E., \& Salamouris, S. D. (2004). Efficiency Measurement of the Greek Commercial Banks with the Use of Financial Ratios: a data envelopment analysis approach. Management Accounting Research, 15(2), 201-224

Hellmann, T.F., Murdock, K.C., \& Stiglitz, J.E. (2000). Liberalization, Moral Hazard, in Banking and Prudential Regulation: Are Capital Requirements Enough? American Economic Review, 90, 147-65.

Hughes, J. P., \& Mester, L. (1998). Bank Capitalization and Cost: Evidence of Scale Economies in Risk Management and Signaling. Review of Economics and Statistics, 80(2), 314-25.

Hughes, J. P., \& Mester, L.J. (2013). Measuring the Performance of Banks: Theory, Practice, Evidence, and Some Policy Implications. $\quad$ Retrieved from http://www.philadelphiafed.org/research-and-data/publications/working-papers/

Hughes, J.P., \& Moon, C. (1995). Measuring Bank Efficiency When Managers Trade Return for Reduced Risk. Department of Economics Rutgers University Working Paper, No. 1995-20, 1995.

Iannotta, G., Nocera, G., \& Sironi, A. (2007). Ownership Structure, Risk and Performance in the European Banking Industry. Journal of Banking and Finance, 31(7), 2127-2149.

Jacques, K., \& Nigro, P. (1997). Risk-based Capital, Portfolio Risk, and Bank Capital: A Simultaneous Equations Approach. Journal of Economics and Business, 49(6), 533-547.

Jensen, M. C., \& Meckling, W. H. (1976). Theory of the Firm: Managerial Behavior, Agency Costs and Ownership Structure. Journal of Financial Economics, 3(October), 305-360.

Kennedy, P. (2008). A Guide to Modern Econometrics. Blackwell Publishing, Oxford.

Kwakwala, B. K. (2015). The Relationship between Risk, Capital and Efficiency in South African Banks. Wits Business School, University of the Witwatersrand.

Kwan, S., \& Eisenbeis, R. (1997). Bank Risk, Capitalization and Operating Efficiency. Journal of Financial Services Research, 12, 117-31.

Lotto, J. (2018). The Empirical Analysis of the Impact of Bank Capital Regulations on Operating Efficiency. International Journal of Financial Studies, 6(34). https://doi.org/10.3390/ijfs6020034

Mosko, A., \& Bozdo, A. (2016). Modeling the Relationship between Bank Efficiency, Capital and Risk in Albanian Banking System. Procedia Economics and Finance, 39, 319-327.

Odunga, R. M. (2016). Specific Performance Indicators, Market Share and Operating Efficiency for Commercial Banks in Kenya. International Journal of Finance and Accounting, 8, 135-145.

Rime, B. (2001). Capital Requirements and Bank Behaviour: Empirical Evidence for Switzerland. Journal of Banking and Finance, 25(4), 789-805.

Salas, V., \& Saurina, J. (2003). Deregulation, Market Power and Risk Behaviour in Spanish Banks. European Economic Review, 47, 1061-1075.

Seodarto, M. (2004). Factor that Affects Distribution Rural Credit Bank [BPR (Rural Bank) Case Study in Work Area Bank Indonesia Semarang]. Thesis. Magister Management Study Program Diponegoro University, Semarang.

Tan, Y., \& Floros, C. (2013). Risk, Capital and Efficiency in Chinese Banking. Journal of International Financial Markets, Institutions and Money, 26, 378-393. http://dx.doi.org/doi:10.1016/j.intfin.2013.07.009.

Williams, J. (2004). Determining Management Behaviour in European Banking. Journal of Banking and Finance, 28, 2427-2460. http://dx.doi.org/10.1016/j.jbankfin.2003.09.010.

Yeh, Q. J. (1996). The Application of Data Envelopment Analysis in Conjunction with Financial Ratios for Bank Performance Evaluation. Journal of the Operational Research Society, 47, 980-988. 
Zellner, A. (1962). An Efficient Method of Estimating Seemingly Unrelated Regression and Tests for Aggregation Bias. Journal of the American Statistical Association, 57, 348-60.

\section{Appendix 1.}

Table 1. Name of Selected Scheduled Commercial Banks in Bangladesh

\begin{tabular}{ll}
\hline Name of Selected Commercial Banks & Name of Selected Commercial Banks \\
\hline AB Bank & Mutual Trust Bank Limited \\
Bank Asia & National Bank Limited \\
Islami Bank Bangladesh Limited & Prime Bank Limited \\
Jamuna Bank & Eastern Bank Limited \\
The City Bank Limited & International Finance Investment and Commerce Bank Limited (IFIC) \\
Southeast Bank Limited & Janata Bank Limited \\
Premier Bank & Uttara Bank Limited \\
Social Islami Bank Limited & Standard Bank Limited \\
Dutch Bangla Bank Limited & NCC Bank Limited \\
ONE Bank Limited & Al-Arafah Islami Bank Limited \\
United Commercial Bank & Trust Bank \\
Exim Bank & Pubali Bank Limited \\
Brac BanK Limited & Shahjalal Islami Bank Limited \\
Dhaka Bank Limited & Agrani Bank \\
Mercantile Bank Limited & Rupali Bank \\
\hline
\end{tabular}

Note. Author's Survey.

\section{Copyrights}

Copyright for this article is retained by the author(s), with first publication rights granted to the journal.

This is an open-access article distributed under the terms and conditions of the Creative Commons Attribution license (http://creativecommons.org/licenses/by/4.0/). 